\title{
ANALISIS FINANSIAL SEKTOR MANUFAKTUR MAKANAN DAN MINUMAN YANG TERDAFTAR DI BURSA EFEK INDONESIA (BEI) PERIODE 2011-2015
}

\author{
DHARMANTO \\ Prodi Manajemen STIE Pignatelly Surakarta Jawa Tengah \\ Email: dharmanto@yahoo.com
}

\begin{abstract}
Abstrak
Penelitian ini bertujuan untuk mengetahui pengaruh rasio keuangan (Debt Equity Ratio, Current Ratio) terhadap kinerja keuangan (Return on Equity) dengan (Return on Assets) sebagai variabel moderating. Metode yang digunakan dalam penelitian ini adalah metode deskriptif dan analisi. Alat analisis menggunakan metode regresi berganda dan regresi berganda demoderasi. Populasi dalam penelitian ini meliputi beberapa perusahaan makanan dan minuman yang terdaptar di bursa efek Indonesia (BEI) pada tahun 2011-2015. Teknik pengambilan sampel dalam penelitian ini adalah metode purposive sampling dengan 12 perusahaan barang konsumsi sektor makanan dan minuman sebagai sampel.

Hasil dari penelitian ini menunjukan bahwa secara parsial Debt Equity Ratio terhadap Return on Equity tidak berpengaruh dan tidak singnifikan. Begitupun Current Ratio terhadap Return on Equity juga tidak berpengaruh dan tidak signifikan. Pada pengujian berikutnya variabel Debt to Equity dan Current Ratio yang diperkuat (minusnya) hubungannya oleh variabel moderating Return on Assets terhadap Return on Equity.
\end{abstract}

Kata kunci: Debt Equity Ratio, Current Ratio, Return on Assets dan Return on Equity.

\section{PENDAHULUAN}

Setiap perusahaan dalam menjalankan kegiatan usaha tentunya memiliki tujuan tertentu, dan salah satunya yaitu memperoleh keuntungan. Tujuan tersebut dapat tercapai apabila manajemen perusahaan bekerja dengan tingkat efektivitas tinggi (Mayasari, 2012). Tingkat efektivitas manajemen yang ditunjukkan dari laba hasil penjualan atau pendapatan investasi dapat diketahui melalui rasio profitabilitas yang dimiliki (Kasmir, 2014:114).

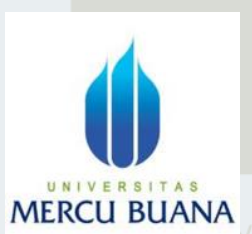

Jurnal Perilaku Dan Strategi bisnis

Vol.5 No.2, 2017

Hal. $221-230$

Profitabilitas merupakan gambaran kemampuan modal perusahaan dalam menghasilkan keuntungan. Keuntungan yang tersedia bagi pemegang saham atas modal yang diinvestasikan diukur melalui rasio return on equity (ROE). ROE yang baik membawa implikasi pemegang saham akan mendapatkan bagian yang besar dari laba, selain itu kreditor merasa aman karena hutang yang diberikan dijamin oleh pemegang saham. Hal 
inilah yang membuat investor dan kreditor tertarik untuk menanamkan dananya (Walsh, 2004:56).

Dana yang berasal dari hutang dibutuhkan perusahaan karena pembiayaan kegiatan operasional tidak dapat ditutup hanya dengan dana dari dalam perusahaan. Penggunaan hutang membantu perusahaan menghasilkan laba walaupun hutang tersebut menimbulkan beban tetap (bunga). Beban tetap dari hutang dapat ditutup dengan laba, namun jika perusahaan gagal menjalankan bisnisnya dan tidak mampu membayar beban tetap tersebut maka risikonya perusahaan akan bangkrut dan merugikan pemegang saham (Jannati, Saifi, \& Endang, 2014). Tambahan sumber dana yang menimbulkan beban tetap ini disebut dengan leverage. Leverage ratio (rasio solvabilitas) mengukur besarnya hutang yang digunakan untuk membiayai kegiatan usaha jika dibandingkan dengan modal sendiri, serta berapa besar hutang tersebut dialokasikan untuk membiayai aktivanya (Kasmir, 2014:113). Merujuk pada penelitian sebelumnya (Henny yulsiasti (2016) Debora setianti santoso (2009)Aminatuzzahra (2010) ,Zainal (2013) Zulfadli (2013), Buchary jahja (2002) Henny yulsiasti (2016 Farida titik (2012), Jihan salim (2015), Yuli orniati (2009). rasio leverage yang digunakan dalam penelitian ini meliputi debt to equity ratio (DER), dan current ratio(CR), dan Return on assets (ROA). Tulisan ini bermaksud untuk meneliti apakah rasiorasio tersebut mempengaruhi ROE pada perusahaan barang konsumsi sektor makanan dan minuman yang terdaftar di BEI periode 2011-2015. Perusahaan makanan dan minuman menarik untuk dijadikan objek penelitian karena sektor ini merupakan salah satu pendukung keperluan/kebutuhan sehari-hari dan memiliki peran penting dalam menunjang perekonomian.

\section{TINJAUAN PUSTAKA}

ROE mengukur kemampuan perusahaan memperoleh laba yang tersedia bagi pemegang saham. Rasio ini juga dipengaruhi oleh hutang perusahaan, apabila proporsi hutang semakin besar maka rasio ini juga akan semakin besar. ROE yang semakin tinggi semakin baik, berarti posisi pemilik perusahaan semakin kuat (Sartono, 2010:124). Pertumbuhan ROE menggambarkan prospek perusahaan yang cemerlang karena berarti ada potensi peningkatan perolehan keuntungan. Hal ini dilihat sebagai sinyal positif oleh para investor, dan para kreditor pun akan merasa aman untuk memberikan pinjaman (Kusumajaya, 2011). Perusahaan yang menggunakan tambahan sumber dana dari pinjaman akan lebih berisiko. Risiko keuangan mengacu pada pendanaan yang menimbulkan biaya tetap, yaitu hutang (financial leverage), dan risiko keuangan ini adalah tambahan risiko yang ditanggung pemegang saham biasa akibat penggunaan leverage keuangan tersebut. Sehingga hal ini akan meningkatkan tingkat pengembalian yang dikehendaki pemegang saham (ROE) (Brigham \& Houston, 2001:14-16).

Merujuk pada penelitian sebelumnya (Henny yulsiasti (2016) Debora setianti santoso (2009)Aminatuzzahra (2010) ,Zainal (2013) Zulfadli (2013), Buchary jahja (2002) Henny yulsiasti (2016 Farida titik (2012), Jihan salim (2015), Yuli orniati (2009). rasio leverage yang digunakan dalam penelitian ini meliputi debt to equity ratio (DER), dan current ratio(CR), dan Return on assets (ROA) terhadap Return on equity (ROE).

1. Debt to Equity Ratio

Bagi perusahaan sebaiknya hutang tidak melebihi modal sendiri agar beban hutang tetapnya tidak terlalu tinggi. Dimana Debt to Equity Ratio yang tinggi menujukan struktur 
pemodalan usaha yang lebih banyak memanfaatkan hutang terhadap ekuitas. Perusahaan dengan laba bertumbuh mempunyai kesempatan yang profitabilitas dalam mendanai investasinya secara internar sehingga perusahaan menghindar untuk menarik dana dari luar dan berusaha mencari solusi yang tepat atas masalah-masalah yang terkait dengan hutangnya, selain itu dengan profitabilitas yang meningkat akan mengangkat laba ditahan. Sehingga akan mnegurangi minat perusahaan untuk melakukan pinjaman dan Debt to Equity Ratio menurun. Barclay, Smith dan Wats, (1998) yang dikemukakan Subakti (2001).

Karena hutang mempunyai dampak yang buruk terhadap kinerja perusahaan, tingkat hutang yang semakin tinggi berarti beban bunga akan semakin besar yang artinya akan mengurangi keuntungan. Semakin tingginya Debt to Equity Ratio menunjukan semakin besar beban perusahaan pihak luar. Hal ini sangat memungkinkan menurunnya kinerja perusahaan, karena tingkat ketergantungan dengan pihak luar semakin tinggi. Maka pengaruh Debt to Equity Ratio terhadap Ratio On Equity adalah negatif. Brigham dan Houston (2001). Debt to Equity Ratio akan bernilai positif apabila perusahaan dapat mengolah pinjaman untuk modal maka profitabilitas akan meningkat. Fitri (2008).

2. Current Ratio

Current ratio merupakan ukuran yang paling umum digunakan untuk mengetahui kesanggupan memenuhi kewajiban jangka pendek, karena rasio ini menunjukan seberapa jauh tuntutan dari kreditor jangka pendek dipenuhi oleh aktiva yang diperkirakan menjadi uang tunai dalam periode yang sama dengan jatuh tempo utang. Menurut Agnes Sawir (2003)

Distribusi dari aktiva lancar yang tidak menguntungkan, misalnya jumlah persediaan yang relatif tinggi dibandingkan dengan taksiran tingkat penjualan yang akan datang sehingga tingkat perputaran persediaan rendah, itu menujukan adanya over investment dalam persediaan tersebut atau adanya saldo pitutang yang besar yang mungkin sulit untuk ditagih. Jadi kegunaan aktiva lancar adalah untuk mengurangi jumlah hutang lancar, sedangkan hutang lancar digunakan untuk menambah aktiva lancar.

Jika aktiva lancar yang dimiliki perusahaan lebih kecil dari pada hutang lancar, dan perusahaan akan mengalami kesulitan dalam megoprasikan perusahaannya. Ini dikarenakan terlalu banyak modal kerja mengakibatkan banyak dana yang menganggur sehingga dapat menurunkan laba. Dengan demikian sangat dimungkinkan bahwa hubungan antara Current Ratio dengan Return On Equity adalah negatif. Current Ratio yang mengakibatkan perubahan jumlah aktiva lancar atau hutang lancar yang keduanya mengakibatkan perubahan terhadap Current Ratio, yang artinya menyebabkan perubahan tingkat likuiditas. Nilai likuiditas yang terlalu tinggi berdampak kurang baik terhadap earning power karena menujukan kelebihan modal kerja yang dibutuhkan, kelebihan ini akan menurunkan kesempatan memperoleh keuntungan. Riyanto (1996).

3. Return On Asset

Return On Asset dan Return On Equity kedua rasio ini mempunya hubungan yang sangat erat, karena kedua rasio ini digunakan untuk menghitung atau mengukur kemampuan perusahaan setelah pajak dari setiap rupiah penjualan. Dengan meningkatnya Return On Asset makan Return On Equity akan meningkat juga dan hal tersebut akan menarik para 
investor, karena Return On Equity yang tinggi menandakan laba yang diterima perusahaan juga tinggi.

Return On Asset merupakan rasio yang menunjukkan hasil (return) atas jumlah aktiva yang digunakan dalam perusahaan. Return On Asset merupakan suatu ukuran tentang efektivitas manajemen dalam mengelolah investasinya. Di samping itu hasil pengembalian investasi menunjukkan produktivitas dari seluruh dana perusahaan, baik modal pinjaman maupun modal sendiri. Semakin rendah (kecil) rasio ini semakin kurang baik, demikian pula sebaliknya. Artinya rasio ini digunakan untuk mengukur efektivitas dari keseluruhan operasi perusahaan. Menurut Kasmir (2008) Return On Assets (ROA) merupakan rasio yang menunjukkan hasil (return) atas jumlah aktiva yang digunakan dalam perusahaan. Dan menurut I Made Sudana (2011) mengemukakan bahwa "Return On Assets (ROA) menunjukan kemampuan perusahaan dengan menggunakan seluruh aktiva yang dimiliki untuk menghasilkan laba setelah pajak.

\section{MODEL KERANGKA PEMIKIRAN}

Berdasarkan landasan teori yang telah diuraikan sebelumnya, serta adanya hasil dari penelitian-penelitian terdahulu, dapat diketahui bahwa Debt to Equity Ratio, Current Ratio, dan Return On Asset mempunyai pengaruh terhadap Return On Equity. Oleh karena itu kerangka pemikiran yang dapat digambarkan adalah sebagai berikut:

Gambar 1. Kerangka Pemikiran

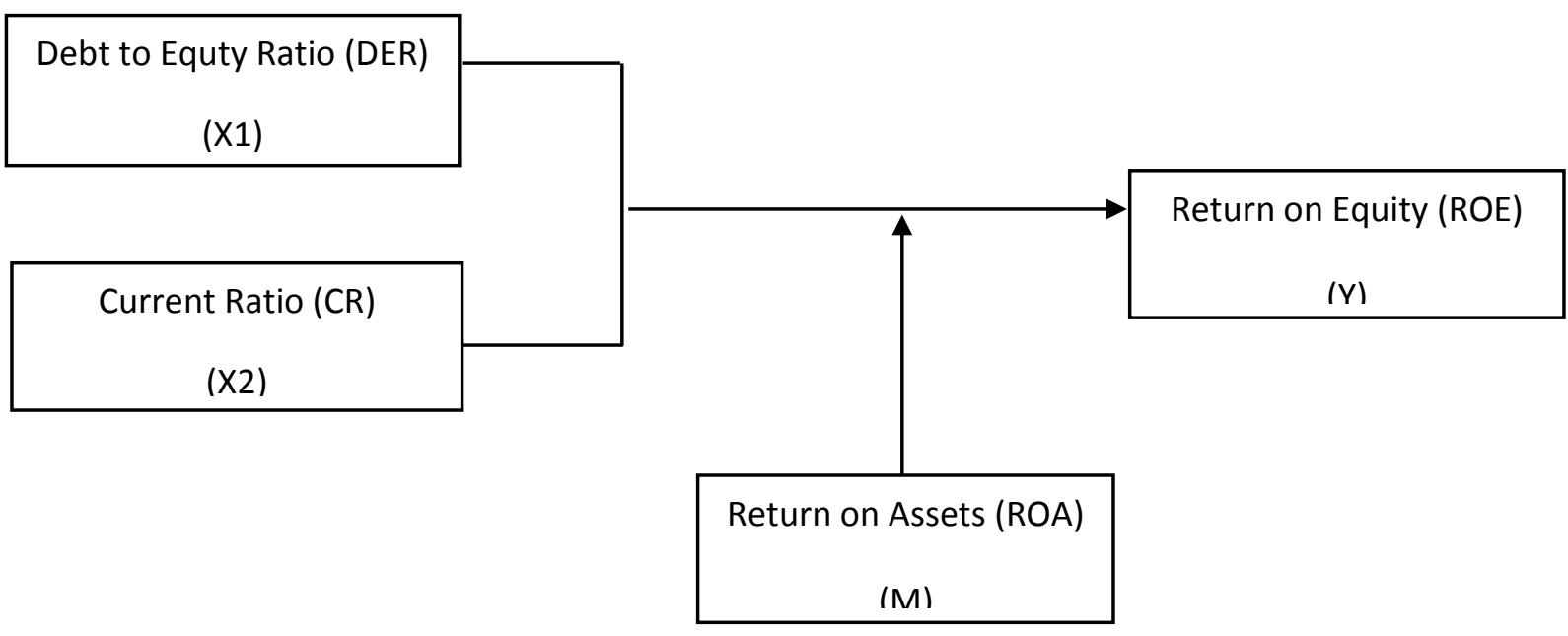

\section{POPULASI DAN PENENTUAN SAMPEL}

Populasi dalam penelitian ini adalah perusahaan yang bergerak di sektor properti dan real estate dan terdaftar sebagai publik (emiten) di Bursa Efek Indonesia. Pemilihan sampel menggunakan metode purposive sampling, dengan kriteria sebagai berikut:

1 Perusahaan makanan dan minuman yang terdaftar di Bursa Efek Indonesia selama periode 2011-2015.

2 Perusahaan tersebut secara periodik mempublikasikan laporan keuangan yang telah diaudit selama periode 2011-2015.

3 Perusahaan makanan dan minuman yang selalu menghasilkan laba atau tidak mengalami kerugian selama periode penelitian. 
4 Perusahaan tersebut menyertakan hutang jangka panjang dalam memenuhi kebutuhan dananya selama periode penelitian.

5 Data keuangan yang dibutuhkan dapat diperoleh di laporan keuangan selama kurun waktu penelitian yaitu tahun 2011-2015.

Berdasarkan kriteria tersebut diperoleh sampel penelitian sebanyak 12 perusahaan. Jenis data yang digunakan dalam penelitian ini adalah data sekunder berupa data keuangan, yaitu laporan keuangan tahunan perusahaan makanan dan minuaman selama periode 2010-2014 yang telah diaudit dan diperoleh melalui website resmi Bursa Efek Indonesia (www.idx.co.id).

\section{METODE ANALISIS DATA}

Teknik analisis pada penelitian ini menggunakan data panel, dan alat pengolahan data dibantu dengan program SPSS 21. Sebelum melakukan pemilihan model regresi, terlebih dahulu dilakukan Analisis Satistik Deskriptif, uji asumsi klasik. Uji asumsi klasik terdiri dari:

1 Analisis Satistik Deskriptif

Pada analisi ini akan dijelaskan mengenai data-data satatistik yang berkaitan dengan mean, satandar deviasi, nilai maksimum dan nilai minimum pada masing-masing variabel yang diambil dari penelitian yaitu : variabel Debt to Equity Ratio, Current Ratio, Returnt On Asset, dan Returnt On Equity. Pengujian ini statistic deskriptif ini menggunakan Software Statistical Package For Social Science.

2 Uji Normalitas

Uji normalitas adalah sebuah uji yang dilakukan dengan tujuan untuk menilai sebaran data pada sebuah kelompok data atau variabel, apakah sebaran data tersebut berdistribusi normal ataukah tidak. Uji normalitas berguna untuk menentukan data yang telah dikumpulkan berdistribusi normal atau diambil dari populasi normal. Metode klasik dalam pengujian normalitas suatu data tidak begitu rumit. Berdasarkan pengalaman empiris beberapa pakar statistik, data yang banyaknya lebih dari 30 angka ( $\mathrm{n}>30$ ), maka sudah dapat diasumsikan berdistribusi normal. Biasa dikatakan sebagai sampel besar, akan tetapi belum tentu juga data yang lebih dari 30 bisa dipastikan berdistribusi nomal.

3 Uji Multikolinearitas

Uji multikolinearitas digunakan untuk mengetahui ada atau tidaknya penyimpangan asumsi klasik multikolinearitas yaitu adanya hubungan linear antar variabel independen dalam model regresi. Prasyarat yang harus terpenuhi dalam model regresi adalah tidak adanya multikolinearitas.

Pada dasarnya multikolinearitas terdiri dari dua macam. Pertama, multikolinearitas sempurna, yaitu apabila antar satu atau semua variabel bebas memiliki korelasi linier. Misal X1 $=5^{*} X 2$. Keadaan semacam ini disebut miltikolinear sempurna. Kedua, antar satu atau semua variabel bebas memiliki korelasi tidak linier, misal X1 $=$ X22. Keadaan ini disebut multikolinear tidak sempuna, namun bukan berarti tidak terjadi multikoliner.

Akibat dari uji multikolineritas terdiri dari beberapa permasalahan dalam model yang digunakan. Permasalahan tersebut adalah, menurut Gujarati, Damodar N (1988): Pertama, estimasi OLS meskipun best, linear, unbiased equation (BLUE), namun varian dan kovarian besar, sehingga sulit ditemukan estimasi yang tepat. Kedua, inteval kepercayaan membesar sehingga cenderung untuk menolak Ho. Ketiga, nilai t statistik 
cenderung tidak signifikan. Keempat, meskipun t statistik kecil nilai R2 cenderung besar. Estimasi OLS nya cenderung sensitif terhadap perubahan perubahan data.

4 Uji Autokorelasi

Uji Autokorelasi adalah sebuah analisis statistik yang dilakukan untuk mengetahui adakah korelasi variabel yang ada di dalam model prediksi dengan perubahan waktu. Oleh karena itu, apabila asumsi autokorelasi terjadi pada sebuah model prediksi, maka nilai disturbance tidak lagi berpasangan secara bebas, melainkan berpasangan secara autokorelasi.

Autokorelasi dapat timbul karena berbagai alasan. Sebagai contoh pertama adalah inersia atau kelembaman dari gejala perekonomian yang datanya terbentuk secara runtut waktu. Inersia dapat diartikan beberapa gejala perekonomian mempunyai perilaku yang sama tiap tahun. Misal hasil obsevasi pada satu titik biasanya lebih tinggi dari sebelumnya. Perilaku ini akan terus berlanjut hingga suatu ketika ada gejalan yang menghentikan perilaku ini. Oleh karena itu data observasi sebaiknya bebas. Perubahan meningkat dari suatu variabel tergantung diikuti oleh perubahan yang meningkat pada variabel bebasnya, dan sebaliknya. Gejala ini menyebabkan asumsi klasik yaitu kovarian dari variabel pengganggu tidak sama dengan nol, dengan kata lain ada korelasi antar variabel pengganggu (Thomas, R.L. 1997).

Akibat dari adanya gejala autokorelasi secara kuantitatif mirip dengan apa yang terjadi pada gejala heteroskedastis, yaitu, tidak bias namun tidak efisien pada parameternya dan pengambilan kesimpulan yang salah arah (Jonhston, J. 1991)

5 Uji Heteroskedastisitas

Uji heteroskedastisitas adalah uji yang menilai apakah ada ketidaksamaan varian dari residual untuk semua pengamatan pada model regresi linear. Uji ini merupakan salah satu dari uji asumsi klasik yang harus dilakukan pada regresi linear. Apabila asumsi heteroskedastisitas tidak terpenuhi, maka model regretion dinyatakan tidak valid sebagai alat peramalan.

6 Moderated Multiple Regretion

Variabel moderator $(M)$ adalah variabel pertengahan antara variabel independen $(X)$ dan variabel dependen $(Y)$, variabel moderator ini digunakan untuk mengukur hubungan kasual antara $X$ dan $Y$ dengan menggunakan koefisien regresi. Pengaruh menggunakan analisis variabel moderator dapat melemahkan hubungan antara $X$ dan $Y$ atau sebaliknya malah memperkuat hubungan $\mathrm{X}$ dan $\mathrm{Y}$.

Pengukuran menggunakan moderasi umumnya ditunjukan oleh interaksi variabel $\mathrm{X}$ dan $\mathrm{M}$ dalam menjelaskan variabel $Y$. persamaan berganda berikut diperkirakan seperti ini, yaitu:

$\mathrm{Y}=\mathrm{i}+\mathrm{aM}+\mathrm{bM}+\mathrm{CXM}+\mathrm{E}(1)$

Interaksi $X$ dan $M$ atau koefisien $\mathrm{c}$ mengukur efek moderasi. Perhatikan jalan bahwa langakah-langkah yang efek dan sederhana dari $X$, kadang-kadang disebut efek utama dari $X$, ketika $M$ sama dengan nol. Seperti yang akan terlihat, uji moderasi tidak selalu di operasionalkan oleh XM jangka produk. Mengingat persamaan 1, pengaruh $\mathrm{X}$ terhadap $\mathrm{Y}$ adalah + cM. dengan demikian efek dari $\mathrm{X}$ pada $\mathrm{Y}$ tergantung pada nilai $\mathrm{M}$. 


\section{PENGUJIAN HIPOTESIS}

Uji ini adalah Metode pengambilan keputusan yang didasarkan dari analisis data, baik dari percobaan yang terkontrol, maupun dari observasi (tidak terkontrol). Dalam statistik sebuah hasil bisa dikatakan signifikan secara statistik jika kejadian tersebut hampir tidak mungkin disebabkan oleh faktor yang kebetulan, sesuai dengan batas probabilitas yang sudah ditentukan sebelumnya. Uji hipotesis kadang disebut juga konfirmasi analisis data. Keputusan dari uji hipotesis hampir selalu dibuat berdasarkan pengujian hipotesis nol. Ini adalah pengujian untuk menjawab pertanyaan yang mengasumsikan hipotesis nol adalah benar. Uji hipotesis dengan regresi berganda dengan melibatkan variabel moderating dapat dilakukan dengan tiga cara yaitu uji interaksi, selisih mutlak, dan Uji T (Uji Pengaruh Secara Parsial).

\section{Uji T (Uji Pengaruh Secara Parsial)}

Uji ini digunakan untuk mengetahui apakah variabel independen secara parsial berpengaruh signifikan terhadap variabel dependen. Dimana Return On Equity sebagai variabel dependen dan Debt Equity Ratio, Current Ratio sebagai variabel independen sehingga dapat diketahui seberapa besar pengaruh masing-masing variabel yang dihipotesiskan terhadap Retrun On Equity.

\section{HASIL ANALISIS}

Hasil uji deskriptif Berdasarkan tabel diatas dapat dilihat bahwa ada 60 data dari 2 variabel independen (Debt Equity Ratio, Current Ratio). Pada variabel Debt Equity Ratio rata-ratanya 50.3712 dengan standar deviasi 66.50748. Pada variabel Current Ratio rata-ratanya 116.2990 dengan standar deviasi 161.12075. Pada variabel dependen Return On Equity rata-ratanya 24.6016 dengan standar deviasi 30.13785. Pada variabel moderating Return on Assets rata-ratanya 13.2170 dengan standar deviasi 13.53115 . Berdasarkan hasil uji multikolineritas di atas, dapat ditarik kesimpulan bahwa untuk nilai VIF variabel Debt Equity sebesar 1,049 kurang dari 10 dimana variabel Debt Equity terbebas dari multikolinieritas. Untuk variabel Current Ratio nilai VIF sebesar 1,049 kurang dari 10 dimana variabel Current Ratio terbebas dari multikolinieritas. Pada uji autokorelasi tidak dapat diputuskan apakah terdapat masalah autokorelasi atau tidak, karena DW berada di antara dL dan dU. Berdasarkan uji normalitas, dimana hasil menunjukan pada variabel Debt Equity Ratio dan Current Ratio tidak mengalami perubahan/normal masih dibawah 0,05 dan pada variabel Return on Equity dan Return on Assets menunjukan perubahan dimana hasil menunjukan signifikansi diatas 0,05. Berdasarkan uji heteroskedastisitas, tidak terjadi gejala yang mengandung heterokedastisitas dalam model ini. Berikut merupakan hasil uji $t$, hasil perhitungan tidaknya pengaruh dan tidak signifikan antara variabel independen (Debt Equity Ratio, Current Ratio) terhadap Return On Equity secara parsial. Dan menurut hasil uji t (uji pengaruh secara parsial) dengan variabel moderating. 
Tabel 1. Regresi

Uji T (Uji Pengaruh Secara Parsial)

\begin{tabular}{ccc}
\hline Variabel & $\mathrm{t}$ & sig. \\
\hline DER*ROA & $-6,470$ & 0,000 \\
CR*ROA & $-2,488$ & 0,016
\end{tabular}

Dependen variabel : ROE

\section{Variabel Debt Equity Ratio}

Nilai thitung untuk variabel Debt Equity Ratio sebesar -6,470 dan ttabel sebesar 2,364 dengan $a=0,05$ atau $5 \%$. Dengan demikian thitung $<$ ttabel $(-6,470<2,364)$ dan nilai signifikan sebesar 0,000 lebih kecil dari 0,05 $(0,000>0,05)$ artinya Debt Equity Ratio secara parsial tidak berpengaruh dan tidak signifikan terhadap Return On Equity.

\section{Variablel Current Ratio}

Nilai thitung untuk variabel Current Ratio sebesar -2,488 dan ttabel sebesar 2,364 dengan a $=0,05$ atau $5 \%$. Dengan demikian thitung $<$ ttabel $(-2,488<2,364)$ dan nilai signifikan sebesar 0,016 lebih besar dari 0,05 (0,016>0,05) artinya Current Ratio secara parsial tidak berpengaruh dan tidak signifikan terhadap Return On Equity.

\section{PEMBAHASAN}

1. Pengaruh Debt Equity Ratio terhadap Return On Equity

Debt Equity Ratio merupakan perbandingan antara total hutang dengan modal sendiri.

Pada dasarnya memang perusahaan makanan dan minuman membutuhkan hutang dalam jumlah yang tidak sedikit untuk memenuhi kebutuhan dananya. Besar hutang yang ditambahkan ke neraca akan menigkatkan beban bunga. Berdasarkan hasil penelitian pada pengujian halaman sebelumnya bahwa variabel Debt Equity Ratio terhadap Return On Equity tidak berpengaruh dan tidak signifikan terhadap Return On Equity. Hal ini akan merugikan lebih banyak laba yang tersedia bagi pemegang saham (ROE). Dan bisa dipahami jika biaya yang dipinjam (cost of debt) lebih kecil ini biaya modal sendiri (cost of equity) maka sumber dana dari perusahaan akan efektif dalam menghasilkan laba (menaikan Return On Equity). Semakin tinggi Debt Equity Ratio akan menujukan bahwa komposisi hutang semakin besar dari pada komposisi ekuitas. Dugaan hipotsis ditolak, kaerna Debt Equity Ratio tidak signifikan terhadap Return On Equity. Penelitian ini didukung oleh Agustina dan Silvia (2012) dimana Debt Equity Ratio berpengaruh dan tidak signifikan terhadap Return On Equity.

2. Pengaruh Current Ratio terhadap Return On Equity

Current Ratio merupakan perbandingan antara aktiva lancar dengan hutang lancar. Jika aktiva lancar pada perusahaan sedikit maka, perusahaan akan mengalami kesulitan saat memenuhi hutang lancar pada perusahaan. Berdasarkan hasil pengujian halaman sebelumnya bahwa variabel Current Ratio terhadap Return On Equity tidak berpengaruh dan tidak signifikan terhadap Return On Equity. Hal tersebut bisa dilihat dari kondisi laporan keuangan pada Current Ratio yang tidak stabil atau fluktuatif, bahkan rasio yang 
dimiliki perusahaan berada di atas ukuran normal (angka 2). Yang membuat Current Ratio menjadi tidak berpengaruh dan tidak signifikan.

Kesimpulan di atas biasa dipahami Current Ratio yang terlalu tinggi menujukan kurang baik, karena hal tersebut menujukan banyak asset perusahaan yang menganggur (aktivitas sedikit) dan yang pada akhirnya dapat mengurangi kemampuan laba perusahaan, sehingga tidak berpengaruh dan tidak signifikan. Dugaan hipotesis diterima, karena Current Ratio tidak berpengaruh dan tidak signifikan terhadap Return On Equity. penelitian ini didukung oleh Machfoedz (1994) dimana Current Ratio berpengaruh terhadap Return On Equity.

3. Pengaruh Debt Equity Ratio dan Current Ratio terhadap Return On Equity dengan Return on Assets sebagai moderator

Berdasarkan hasil pengujian halaman sebelumnya bahwa variabel Debt Equity Ratio dan Current Ratio berpengaruh dan signifikan secara persial dan regresi bergandan terhadap Return On Equity dengan Return on Assets sebagai moderator. Hal tersebut membuktikan bahwa Return on Assets signifikan dalam memperlemah hubungan antara variabel independen dengan variabel dependen.

\section{KESIMPULAN}

Berdasarkan dari hasil pembahasan dan penelitian yamg telah dilakukan oleh peneliti, maka kesimpulan dari penelitian ini adalah sebagai berikut :

1. Secara persial variabel Debt to Equity Ratio tidak berpengaruh dan tidak signifikan terhadap Return on Equity.

2. Secara persial variabel Current Ratio tidak berpengaruh dan tidak signifikan terhadap Return on Equity.

3. Secara persial dan regressi berganda variabel Debt to Equity Ratio dan Current Ratio terhadap Return on Equity berpengaruh dan signifikan, dimana Return on Assets sebagai variabel moderating.

\section{SARAN}

Dari kesimpulan diatas peneliti dapat memberikan beberapa saran, yaitu sebagai berikut :

1. Saran bagi perusahaan

Bagi perusahaan disarankan untuk untuk lebih meningkatkan kinerjanya secara menyeluruh dalam segala aspek sehingga dapat kinerja keuangan dimasa yang akan datang

2. Saran bagi peneliti selanjutnya

a. Bagi peneliti yang berminat untuk melakukan penelitian lebih lanjut mengenai variabelvariabel yang mepengaruhi kinerja keuangan diharapkan untuk menambah atau menganti varibel independen atau dependen pada penelitian.

b. mengembangkan penelitian seperti menambah periode penelitian agar dapat memberikan hasil yang lebih baik.

\section{DAFTAR PUSTAKA}

Henny yulsiasti (2016), Pengaruh Debt to Assets Ratio, Debt to Equity Ratio dan Net Profit Margin Terhadap Return on Equity pada Perusahaan Properti dan Real Estate yang Terdaftar di Bursa Efek Indonesia. 
Debora setianti santoso (2009), Analisis pengaruh current ratio, debt to equity ratio, total asset turnover, net profit margin terhadap return on equity

Aminatuzzahra (2010), Analisis Pengaruh Current Ratio Debt to Equity Ratio , Tottal Asset

TurnOver, Net Profit Margin terhadap ROE studi kasus perusahaan manufaktur Go-Public di BEI"',

Zulfadli (2013), Pengaruh Current Ratio, Debt to Equity Ratio, Debt Asset Ratio, Net Profit Margin, Gross Profit Margin terhadap Return on Equity

Buchary jahja (2002), Analisis Pengaruh Current Ratio Debt to Equity Ratio , Tottal Asset TurnOver, Net Profit Margin terhadap ROE

Jihan salim (2015), Pengaruh Leverage (DAR, DER dan TIER) terhadap ROE. Perusahaan

Properti dan Real Estate yang terdaftar di Bursa Efek Indonesia tahun 2010-2014. 